\title{
GCU
}

Glasgow Caledonian

University

University for the Common Good

\section{Social enterprises in quasi-markets: Exploring the critical knowledge gaps}

Mason, Chris; Roy, Michael J.; Carey, Gemma

Published in:

Social Enterprise Journal

DOI:

10.1108/SEJ-09-2018-0061

Publication date:

2019

Document Version

Author accepted manuscript

Link to publication in ResearchOnline

Citation for published version (Harvard):

Mason, C, Roy, MJ \& Carey, G 2019, 'Social enterprises in quasi-markets: Exploring the critical knowledge gaps', Social Enterprise Journal, vol. 15, no. 3, pp. 358-375. https://doi.org/10.1108/SEJ-09-2018-0061

\section{General rights}

Copyright and moral rights for the publications made accessible in the public portal are retained by the authors and/or other copyright owners and it is a condition of accessing publications that users recognise and abide by the legal requirements associated with these rights.

Take down policy

If you believe that this document breaches copyright please view our takedown policy at https://edshare.gcu.ac.uk/id/eprint/5179 for details of how to contact us. 
Social enterprises in quasi-markets: Exploring the critical knowledge gaps

\section{Chris Mason}

CSI Swinburne, Swinburne University of Technology, Hawthorn, Victoria, Australia

Michael J. Roy

Yunus Centre for Social Business and Health, Glasgow Caledonian University, UK

Gemma Carey

CSI UNSW, University of New South Wales, Sydney, Australia

\section{Authors' Pre-publication Version}

Cite as:

Mason, C., Roy, M.J., Carey, G. (2019) Social Enterprise in Quasi-Markets: Exploring the Critical Knowledge Gaps. Social Enterprise Journal (15) 


\section{Introduction}

Social enterprises are receiving increasing attention in policy research, as a result of their growing importance in the delivery of welfare services (Teasdale, Lyon and Baldock 2013; Alcock 2014). With challenging fiscal conditions determining real-terms investment in welfare markets (Lowery 1998), social enterprise engagement is emerging as a tactical policy response to increase the effectiveness and efficiency of welfare provision - particularly with the rise of social service markets (Dey and Teasdale 2016). In this article, we focus on how social enterprises fit with the continued evolution of quasi-markets, conceptualised as situations where government reduces its role as both direct funder and provider of public services (Le Grand 1991). Although the prospect of social enterprises entering into quasimarkets offers rich potential in advance to both theory and practice, the latter outpaces the former. Indeed, the nascence of this field, and the strongly contested nature of both quasimarkets and social enterprise as independent concepts begets a close examination of the critical gaps present in the current research literature. In response to this, we are driven by the following research question: what are the critical knowledge gaps concerning social enterprise in quasi-markets?

In this paper we explore and critique how social enterprises have been described in quasimarkets research in recent years. Research indicates an increasingly important role for social enterprises in the design and delivery of welfare services and are being encouraged by policymakers to participate in contracting arrangements to deliver services using business models akin to those used by private sector providers. The distinct (and largely assumed) competitive advantage afforded to social enterprises is their intrinsic social mission. The social mission serves as their primary focus, directly shaping the design and delivery of their services (Blackburn and Fox 2006). A number of recent articles have begun to address the presence of social enterprises in particular health and social care markets, largely in the United Kingdom and continental Europe (e.g. Miller, Millar and Hall 2012; Millar, Hall and Miller 2013). However, internationally social enterprise is featuring in policy documents as offering potential solutions to quasi market challenges (Institute of Public Care 2015). Findings among these studies into social enterprise and quasi-markets are mixed, with some suggesting a 
degree of success in integrating social enterprise models into these markets, while others highlight some critical failings in the implementation of particular social enterprise models. Hence, at present, the evidence and debate is contested and further clarity is needed, particularly given the growing interest from policy makers in the role of social enterprises in overcoming quasi-market challenges. Based on a review of the literature we identify critical knowledge gaps which, if addressed, would bring clarity to the current state of the field. While the review predominately draws on research from the UK (where these issues are best documented), the findings offer important insights internationally.

The article is structured as follows. First, we provide contextual framing through a discussion of the rise of quasi-markets as a product of New Public Management (NPM) and latterly, New Public Governance (NPG). Next, we determine the systems and organisation-level focus of social enterprise/quasi-market literature, largely focusing on the dominance of UK-based research and drawing from other jurisdictions that offer comparative insights. This is followed by a discussion of the critical implications for social enterprise development in quasi-markets. We conclude the article by drawing out core issues for scholars, policymakers and practitioners in further developing systems to provide capacity building opportunities in quasi-markets.

\section{Social enterprises and quasi-markets: contextual background}

\section{The rise of quasi-markets}

Over the past twenty years, government reforms to welfare and public services have created new markets and opportunities for organisations in many countries (Kendall 2000; Considine 2003; Lewis 2005). Alongside formalising relationships between state and third sector, such as through 'compacts', governments have progressively reformed welfare markets into socalled 'quasi-markets' (Taylor and Bassi 1998; Kendall 2000; Hall, Alcock and Millar 2012). Quasi-markets arise where government reduces its role as both direct funder and provider of public services; where 'the provision of a service is undertaken by competitive providers as in pure markets, but where the purchasers of the service are financed from resources provided 
by the state instead of from their own private resources' (Le Grand 2011a: p. 80; Bartlett and Le Grand 1993).

In his assessment of the changes to British social policy in the early 1990s, Le Grand predicted that significant changes to Government provision of state-run services could lead to resolving key problems with state-run services. First among them is the assertion that the state waste resources on bureaucratic and administrative functions, investment that could otherwise be better directed to the service 'front-line', or other important fiscal priority areas in public life, such as building new schools.

Secondly, Le Grand argues that the quasi-market approach might also deal with issues of equity, whereby the centralised delivery of services is "unresponsive to the needs and wants of the very people it was set up primarily to help: the poor and disadvantaged" (Le Grand, 1991, p. 1262). Thus, quasi-markets aim to deal with X-inefficiency; that is, the difference between an organisation's theoretically efficient behaviour versus that observed in practice. Quasi-markets supposedly confront the lack of observed efficiency by encouraging competition while also tackling a second problem of allocative inefficiency. This means that services are produced for the public that produce a sub-optimal benefit based on the level of resources employed to produce the service. State-run services are often considered to be rather poor at making efficient use of their resources whilst producing optimal levels of benefit for users. In either case - inefficiency or inequity - it is clear to see why governments would want to develop markets that reduce the fiscal burden on the state, encourage nonstate actors to organise service delivery, and enhance the perception of public value.

Although the ongoing reform of National Health Service (NHS) provision in England represents one of the largest public sector reform processes in recent history, quasi-markets have arguably been more successfully developed in other countries. For example, New Zealand, who readily embraced these opportunities as part of the 'social experiment of the New Right' (O'Brien and Wilkes 1993; McLean and Ashton 2001), and Australia (Considine, O'Sullivan and 
Nguyen 2014) have, in slightly differing trajectories, developed new approaches to traditionally state run services.

The development and implementation of the markets has often been linked with NPM, which accelerated public sector reforms in many developed economies (Dunleavy and Hood, 1994). Considine et al. (2014, p. 814) explain that NPM was "designed to promote increased public sector efficiency, including through forms of privatisation". NPM resulted in a shift to lateral coordination between government departments, flat and decentralised structures to enable more effective (local) decision making and, in turn, the development of quasi-markets. The key to unlocking more effective public value, it was argued, was to create a competitive environment which would give public service uses greater choice while reducing costs for government. Internationally, governments took action to make these reforms across Europe, North America and Australasia (McMaster, 2002). quasi-markets now exist primarily in care and welfare based services, such as health care (Exworthy, Powell and Mohan, 1999), childcare (Penn, 2007), education (Adnett and Davies, 2003), disability (Carey et al., 2017a; Glasby and Littlechild, 2009; Needham, 2010) and aged care (Baxter, Rabiee and Glendinning, 2013; Braithwaite, Makkai and Braithwaite, 2007; Glasby and Littlechild, 2009)

The still emerging NPG paradigm is predicated upon what Osborne (2006: p.384) posits as the notion of both a plural state 'where multiple inter-dependent actors contribute to the delivery of public services' and a pluralist state 'where multiple processes inform the policy making system'. As Osborne and others (O'Flynn 2015) note, NPG is also characterised by a layering of old and new approaches to governance and administration, meaning that NPM continues to exert influence. NPG is highly focused upon inter-organizational relationships and the governance of processes, while still stressing service effectiveness and outcomes, NPG emphasizes the design and evaluation of inter-organizational relationships 'where trust, relational capital and relational contracts act as the core governance mechanisms' (Osborne 2006: p.384). Such an emphasis leads to what Bovaird (2006) recognizes as new forms of partnership with the market in the provision of public services, with the quasi-market best exemplifying this process. 
The focus on the governance of inter-organizational relationships has intensified pressures to 'open up' public sector markets to increased participation (thus, competition) among forprofit private, non-profit and social enterprise organisations in contracting the delivery of key public services. Through such processes, policy makers aim to reduce the likelihood of escalating fiscal costs attached to public service provision, while hoping to improve the efficiency and effectiveness of service delivery in the interim. Research has explored the viability of the latter claim of quasi-market efficiency and effectiveness in some depth, especially the way for-profit and traditional non-profit organisations respond in such conditions (e.g. Struyven and Steurs 2005, Considine 2003, Buckingham 2009). However, it is regarding social enterprises where practice currently outpaces empirical observations and theoretical developments.

Social enterprises are 'hybrid' organisations, combining social and business logics, and are conceptually framed between organisational and sector boundaries (following Brandsen, van de Donk and Putters 2005, Billis 2010). Social enterprises have several forms and origins: some scholars emphasise their emergence as the market-based activities of traditional nonprofits, while others suggest that they are the inevitable consequence of mainstream business becoming more socially orientated, that profit can be combined with positive social impact.

However, the concept of social enterprise is, in reality, highly contested, variously understood in different geographies, cultures, and at different points in time (Teasdale 2012a). Peattie and Morley (2008: p. 95), for instance, describe the social enterprise field as a 'definitional minefield', comprised of a plethora of organisational types that vary 'in their size, activities, legal structure and ownership, geographic scope, funding, motivations, degree of profit orientation, relationship with communities and culture'. Broadly speaking there are at least two distinct traditions of social enterprise: the approach most often seen in the United States, where social enterprise is seen as commercially sustainable organisations competing against other providers to sell social goods and/or deliver services (Dees 1998; Kerlin 2006); and a continental European approach, which sees social enterprises as hybrid organisations deriving revenue from a range of sources, working collaboratively with governments to deliver goods and services within a mixed economy of welfare (Defourny and Nyssens 2010; 
Evers 2008). In reality, though, most countries tend to borrow from both traditions, and so it can be recognised that social enterprises owe an ideological legacy to charities and nonprofits, with the prioritising of social or environmental mission and the needs of defined (social) beneficiaries ahead of profit maximisation.

The hybrid nature of social enterprise means that they differ from traditional non-profits by virtue of the centrality of trading income as part of their business models (Battilana and Lee, 2014; Smith 2010). Social enterprises intend to re-invest the majority of the surplus they create back into their business and, in some forms, they can deliver a dividend or profit to key community stakeholders. Thus, they exist to create social impact through trade, rather than solely to serve a social mission. According to Smith (2010) hybridization represents an 'adaptive response' by third sector organizations to the turbulence caused by the reconfiguration of state and market relations.

The conceptual ambiguities that accompany any discussion of social enterprises can create significant challenges (Dey and Teasdale 2013). For instance, while charities and non-trading non-profits are significantly affected by marketization, social enterprises are designed to embed revenue creation through trade from inception, making them potentially less susceptible to the impacts of marketization pressures. Metaphorically, social enterprises are a 'double agent', at once part of the third sector by virtue of their historical origins and social orientations, yet distinctive from it due to their hybridity and politicisation (Dey and Teasdale 2013).

If social enterprises are a conceptually distinctive constituent of the third sector, some researchers have argued this is partly due to their treatment as a political subject (Mason 2012; Teasdale 2012b). In other words, political influence in developing the capacity for social enterprises to develop has also helped to create a market-ready organisational form to work in quasi-markets. For example, the political encouragement for social enterprise development, such as the United Kingdom and Australia, has been framed in part by the potential market opportunities created by the state through the development of quasimarkets (Cornelius and Wallace 2013). In the next section, we explore the impact of social 
enterprise participation in specific welfare markets. In so doing, we reflect on available evidence to understand the impact of social enterprises compared with other organisations, such as for-profit, public and non-profit providers.

\section{Social enterprises and quasi-markets: where do they fit?}

Given the high level of government investment in capacity development for social enterprise in some countries, it is perhaps unsurprising that those operating in health and social care services have received particular attention (Calò et al, 2018; Roy et al, 2013; Hall, Miller and Millar 2016). As the example of the NHS in England shows, governments can re-engineer an existing market to develop new opportunities for social enterprise capacity building (Millar, Hall and Miller 2013). Furthermore, it could also be argued that as a political construction, social enterprise is an expedient political vehicle to perform front-line public service delivery (Borzaga and Fazzi 2014; Ferguson 2012). Moreover, as on-going challenges with quasimarkets continue to emerge, governments are increasingly turning to social enterprise as a potential solution (Carey, Dickinson, Malbon and Reeders 2017).

The hybrid business models and dual mission of social enterprise speak directly to the needs of governments seeking to reform the way existing providers deliver public services (Taylor et al. 2011, Powell, Gillett and Doherty 2019), as well as addressing quasi-market gaps for niche issues that large providers cannot fill appropriately. Thus described, social enterprises look like an ideal and politically legitimate service delivery model for health and social care markets. Studies have addressed the emergence of social enterprise in quasi-markets at system and organisational levels, and we address them in relation to our research question, below.

\section{System-level}

At a system-level, studies have focused on the impact of system-level changes at individual and comparative country-levels, including the development of new market opportunities for social enterprises. Bode, Gardin and Nyssens' (2011) comparison of domiciliary care 
arrangement in Europe and Nordic contexts shows that quasi-markets can have varied, and negative, impacts on the front-line. The work/life balance of front-line staff and adverse dispersion of adequate services appear to be unwelcome consequences of the development of quasi-markets for these services. Other studies have reflected how broader economic and social crises have precipitated a withdrawal from welfare provision in many countries. These system level events, e.g. the sovereign debt crisis in Europe, have encouraged further welfare reforms as a response to austerity. Borzaga and Fazzi (2014) explain how the withdrawal of the state in healthcare provision has created opportunities for social cooperatives in Italy, which in turn indicates how third sector involvement in delivering these services is assisted by forming social enterprises.

Further research suggests that the development of social enterprise in these markets is framed by the same systemic pressures for reform as those facing the third sector more broadly. Hall et al. (2012) argue that policies have been used to develop the supply of social enterprise so they will directly supplement the diversity of healthcare providers. For example, in the United Kingdom, specific social enterprise funding and development programs were created by subsequent New Labour and Coalition governments to accelerate their provision of healthcare services (Hall et al. 2012). In a sense, such programs singled out social enterprises as beneficiaries of reform, whilst casting them as a political subject to increase supplier diversity, competition and service quality. Millar (2012) notes that the assumptions underlying the social enterprise model influence broader isomorphic pressures (viz. DiMaggio and Powell 1983) across other (third sector) providers. He argues that rather than hybridity creating greater diversity, over time, the pressures on third sector providers will be to conform to legitimate structures and processes in order to survive in the quasi-market place (Dart 2004). Thus, we might expect homogeneity, rather than diversity, among competing suppliers.

\section{Organisational-level}

The second major theme among social enterprise studies focuses at the organisational level, considering issues of strategy, culture, identity, values, and performance. Both Cheater (2010) 
and Warrilow and Jones (2012) report practitioner case studies based in the UK, reporting positive experiences among those practitioners about the early stages of developing a new social enterprise. Other studies have been more even-handed, with some scepticism that social enterprise represents a new dawn in health care provision. Millar, Hall and Miller (2013) explored the reorientation of social enterprises seeking to engage in public health systems. They noted how the process of Right to Request (RtR) requires significant re-organising structures and processes, whilst balancing the 'selling' of the mission to the wider system. Building on the idea of re-organising structures and processes, Millar and Hall (2013) argue there is a significant need for effective performance measurement systems in order to help social enterprises be held accountable for their impacts. At the level of governance structures, Veronesi and Keasey (2012) studied the board-level governance reforms in NHS trusts, finding that reforms would likely align these new structures with a social enterprise model and approach. Hall, Miller and Millar (2016) studied NHS 'spin-outs', finding that these new healthcare social enterprises show a melding of public and third sector values, allowing practitioners greater freedom in how they choose to run front-line services. They noted that there are also some obstacles to re-purposing into a social enterprise, such as the dependence on government contract funding which makes 'them especially vulnerable to policy and legislation changes' (Hall et al. 2016: p. 552). Powell et al (2019) examined how social enterprise hybrids can successfully achieve both social and economic logics in a public sector context. Through their analysis of case studies in adult day care environments, they found that social enterprises were able to resolve conflicting logics in financially constrained operating environment. Hence, by virtue of their hybridity, social enterprises can engineer their organisational systems and processes to manage conflicting logics. As such, they recommend social enterprises focus on diversifying their income streams, focus on service quality and developing a 'hybrid workforce' - one that comprises both a care for social mission and beneficiaries, as well as technical competence. They consider these three areas to be good practice for social enterprises working in public sector markets.

When it comes to types of social enterprises involved in quasi-markets, those focusing predominantly on social care appear to favour employment-based models, such as work integration social enterprises (WISEs). One of the most important empirical studies to date 
provided a comparison between types of service provider in a quasi-market (Defourny et al. 2011). Their study reported that, when comparing the performance of for-profit, public, and third sector models in providing employment opportunities in domiciliary care services, WISES perform the best across most aspects of the service relationship. The focus on social as well as efficiency goals of the service put WISEs in a strong position to provide multiple outcomes from their work. This differs from for-profit providers, that may offer the most efficient through-put, but have minimal concern with improving the social impact of the service. Furthermore, Ferguson (2012) argues the mental health field in the United States should focus increased attention upon provision via social firms or Work Integration Social Enterprises (WISEs). In particular, her case study evidence suggests that social enterprises facilitate effective outcomes for participants, as well as collaborations between organisational and institutional partners. Other studies support this claim, especially that undertaken by Powell et al (2019), Although it's worth noting that the type of social enterprise (i.e. the model) could be determined by the expected (and enforced) institutional pressures to adopt specific forms (Pinch and Sunley 2015), rather than one that reflects the social mission and balance of competing logics.

The current evidence of social enterprise activity in quasi-markets thus largely focuses on systems and organisations, especially the impact of new market structures on the development of social enterprises. In the next section, we discuss what the above evidence indicates about how social enterprises fare in quasi-markets compared with third sector providers more generally. In particular, we explore the missing components of scholarly discourses on social enterprise and quasi-markets.

\section{Discussion: Critical Issues for Social Enterprises in Quasi-Markets}

There are several issues with the deployment of the social enterprise model in these markets. Some of these issues are similar of those faced by the third sector more generally, whilst others suggest different kinds of challenges. In this section, we discuss some core and interlinked critical gaps arising from social enterprise engagement in, and through, quasimarkets. These relate to issues of shifting boundaries and marketization; symbolic shifting to 
social enterprise models; a lack of comparative evidence to justify further social enterprise/quasi-market expansion, and a lack of resourcing to embed effective performance reporting.

\section{Gap 1: 'Boundary shift' and moral dilemmas}

In most studies of social enterprises in quasi-markets, the reforms to state-third sector relations prefacing the emergence of social enterprise as service providers is a common theme (Blessing 2012; Warner and Clifton 2014). Yet, very few studies highlight the implications of shifting boundaries between sector and state, and the emergence of moral dilemmas resulting from increased marketization.

Drawing on Bolderson (1982: pp. 290-291), Sinclair et al. (2014) argue that marketization of former public services can change their fundamental character, creating a 'boundary shift' in the relationship between the state and individuals: a reform which fundamentally alters the character of a service in a qualitative manner beyond a simple quantitative or incremental adjustment. Whether a service is motivated to achieve public benefits or private profit is not merely incidental, they argue, but influences factors such as how it is delivered, quality as an entitlement, and the experience of those in receipt of the service. The market relationship between a customer and a seller is qualitatively different from that between a public service user and provider. The introduction of quasi-markets therefore fundamentally alters the character of public services and, moreover, fosters further financialization into the fabric of social and public services (Dowling and Harvie 2014). Such a shift presents several risks and moral dilemmas that require considerable thought and reflection.

Markets, quasi- or otherwise, supposedly function in accordance with considerations of exchange and the incentives of profit and reward to enable the distribution of resources. But government policy is more than just about the efficient (re-) distribution of resources; it is a principle means of articulating a vision of a 'common good', legitimated by public debate and democratic processes. As Sinclair et al. (2014) argue, the process of how this common good vision is realised is more than a mere technicality: social policies are - or are supposed to be 
- guided and encouraged by a set of underlying principles, including, but not limited to, entitlement, desert, need, dignity and fairness (Roy, McHugh and Sinclair, 2017). In other words, what should inform delivery is not simply a narrow focus on the accomplishment of instrumentalist, technical, financial outcomes alone, but should be guided by a set of moral principles. Issues of morality, however, do not seem to have occurred to, let alone troubled, advocates of quasi-markets.

As an illustration, just as quasi-markets started to be introduced, Le Grand (1991: p. 1258) raised a number of questions which still have relevance today:

'What are the likely economic consequences of [the introduction of quasi-markets]? Will they reduce costs and therefore bring about greater efficiency, as their proponents argue? Or will they create other sources of inefficiency while simultaneously causing greater inequity, as their critics allege? We cannot properly answer these questions until the changes have fully worked their way through the system: and this is likely to be several years away.'

The term "likely economic consequences" indicates that Le Grand was (explicitly or implicitly) thinking about the economy in an instrumentalist sense, with a focus on rationality and 'efficiency'. Indeed, efficiency here is limited to efficiency for the public sector. The needs of individuals, communities and wider society would seem, at best, secondary to such considerations, or not considered at all.

Moreover, it is now 25 years since Le Grand raised those questions, and so it seems timely to consider whether we are any closer to some answers. First of all, it is difficult to say with any accuracy as to whether quasi-markets have actually made a difference, even in a narrow, instrumentalist, sense. Take, for example, this later quote from Le Grand (2011b: p. 4) when he discusses the success of market reforms in the NHS in England, as compared to the unreformed health systems of Scotland and Wales: 
'although some of these improvements were undoubtedly due to the increase in resources that characterised the later parts of that period, the relatively poor performance of the better-resourced but unreformed Scottish and Welsh health services suggests that there was more going on than simply increased resources. The targets and terror regime that preceded the market-oriented reforms in England also played a considerable part in the improvement...the research demonstrates that patient choice and provider competition did have an independent effect.'

To support his point, Le Grand draws upon work by Propper et al. (2010), which focuses predominantly upon waiting list times. Although important, waiting times for treatment is just one dimension by which the quality of health services can be assessed. Furthermore, since Le Grand observed these differences, the gaps between the English, Welsh and Scottish health systems has become very marginal indeed on a whole range of different metrics (Bevan et al. 2014). Scotland is actually outperforming England (and, indeed, the rest of the world) in a number of areas, such as in emergency medicine (Nutt 2016). The argument that the introduction of quasi-markets, such as we see in healthcare, inevitably leads to better outcomes is therefore still not proven by any means (and, indeed, has become increasingly doubtful), some 25 years after Le Grand posed his questions above. Thus, we question whether social policies that promote quasi-market development reflect much more than a continued focus on instrumental outcomes (i.e. efficiency). The continued pressure to marketize for social enterprises in these markets is not supported by a groundswell of evidence proving this is the most effective way to either encourage social enterprise capacity building or deliver welfare services.

\section{Gap 2: Symbolic shifting to social enterprise forms}

Given the increasing pressure on resources and threats to their viability, it is worth considering whether existing market participants would tactically shift to social enterprise 'forms' to legitimise their position and obtain resources. The implication here is that quasimarkets are not encouraging entirely new entrants, rather changing conditions encourage isomorphism. When faced with exogenous market pressures (such as strong competition, 
innovations on the market place or changing market structures), organisations tend to undergo structural changes in order to ensure their continued survival in the market.

Organisations could seek to obtain legitimacy in quasi-markets to aid in competitive tendering processes simply by labelling themselves as a 'social enterprise'. Dey and Teasdale (2016) termed this 'tactical mimicry', with the individual they focused upon acting 'as if' he was a social entrepreneur, framing his activities and employing a 'social enterprise discourse' in order to achieve legitimacy and, consequently, funding. We identify this as a significant problem for developing social enterprise engagement in quasi-markets. Since symbolic tactics legitimise one model over another, certain social enterprises may struggle to negotiate their legitimacy and thus establish or grow in the face of competitive pressures that advantage those most able or equipped to create a 'favourable impression' (viz Steiner and Teasdale, 2016). The principal goal of social enterprise development is to encourage the maximization of social impact in welfare markets in the medium to long-term. Thus, we argue that a shortterm approach to organisational strategy risks foregoing the chance to make a significant and sustainable social impact to maximise the risk of survival in the marketplace. It also risks creating social enterprises in name only, where mimicry creates the false impression that the provider is an 'authentic' social enterprise (howsoever determined). The organisation's principal commitment to defined (and measurable) social impact would need to more than a means to an end. Pinch and Sunley (2015) showed that conflicting institutional logics are experienced and managed by social enterprise managers, implying that the institutional pressures increase tension to adopt and adapt hybrid forms to meet expectations of non-core beneficiaries. Indeed, vigilance is needed to understand if and how particular social enterprise models become privileged over others in quasi-markets, and how this differs among quasi-market contexts. Hurri, Vuori, Liddle and Allen (2016) explored the impact of contracting on municipal organisations servicing health care quasi-markets in Finland. They found that contracting increased perceptions of actual costs, meaning organisations were less likely to 'create new networks with vendors or competition between private service providers' (p. 190). Whether this outcome would be the case for other quasi-markets, and for social enterprises working in them is open to debate, but it does indicate unexpected effects of contracting for public services. 
Again, the implication for social policy is to address whether there is a fundamental commitment to the principles, and practical understanding of social enterprise in the welfare economy. This includes both the guiding philosophies and ideas that underpin policy-making, as well as the design of policies and implementation strategies that create authentic and legitimate buy-in from across stakeholder groups. If mechanisms such as social procurement are intended to support and grow the contribution of social enterprises in welfare markets, then they will reflect both of these factors and be evident in the awarding of service contracts in the coming years. The alternative outcome is, as Millar (2012) argued, quasi-markets will encourage competitive mimicry that results in a high degree of homogeneity in place of organisational diversity. We argue that homogeneity would be detrimental to the broader political aims in many welfare markets, for a diverse, sustainable and effective social economy are at the heart of government and society.

\section{Gap 3: Lack of comparative evidence of social enterprise and quasi-markets}

The third major constraint is the relative lack of evaluative evidence supporting both the inclusion of social enterprises in quasi-markets, as well as their performance. There are only a couple of studies that address comparisons between third sector, social enterprise and other organisations in a welfare delivery system. Although we acknowledge that our literature overview is UK-centric, specific social enterprise and quasi-market studies are just starting to emerge in other jurisdictions. That said, there is still the problem of understanding comparative similarity and difference between social enterprise activities in different quasimarkets, and between jurisdictions. Much of the existing research has been conducted in the context of the NHS in England and Scotland. For example, particular social enterprise studies have been focused on developing new services from within existing infrastructures (such as NHS spin-outs - see Hazenberg and Hall 2016).

In a review of elderly domiciliary quasi-marketization in four countries Bode et al. (2011) argued that the needs of both front-line staff and care recipients are dramatically affected by the institutional arrangements guiding market development. Although they noted that European and Nordic 'cultural colouring' can facilitate quasi-market conditions that to meet 
the needs of both groups, they contend that economic and social uncertainties create new problems for how future markets are designed and implemented.

As we have noted above, there are also a small number of specific studies focusing on social enterprises working in quasi-market contexts (i.e. WISEs). Defourny et al's (2010) study is one of the few that offer a thorough analysis of a robust data set, in that they compare social enterprise performance to private for-profit, non-profit and traditional public sector providers. Aiken and Bode (2009), in their analysis of organisations operating in the 'Back to Work' employability programme, which is organised along quasi-market lines in the UK, found that 'emerging managerialist partnership structures' caused the WISEs they studied to convert into 'just in time deliverers of poor programme outcomes' (Aiken and Bode 2009: p. 209), while, at the same time, eroding the distinctiveness (and thus the advantages) of the organizational form in comparison to for-profit providers.

However, there remains a distinct lack of evidence across multiple jurisdictions describing and explaining exactly how social enterprises have been integrated into specific quasi-markets. The manner of integration is important, since it will likely be framed by prevailing political climates in a given jurisdiction. In order to be instructive as to how effective particular social enterprise integration policies have been, research would need to account for local welfare needs and provision, as well as policy design and implementation. Indeed, taking the United Kingdom as an example, the high level of investment has created capacity (and demand) for social enterprise, in tandem with the emergence of NPM and NPG to encourage 'third sector' participation in public service delivery more broadly (Carmel and Harlock 2008). These actions are recognised as a strong indicator of how the UK government has supported the gradual inclusion of social enterprise into quasi-markets (e.g. in the NHS in England) over a prolonged period. Such knowledge is important for understanding the implications for crossjurisdictional policy learning, and at a time when quasi-market development appears to be on the rise in a time of increasing austerity and welfare uncertainty. 


\section{Gap 4: Resource needs for rigorous impact measurement}

A final critical issue to be addressed is how social enterprises can be measured on their performance in a way that recognises the multiple benefits they create through their work (Paton 2003). Defourny et al (2010) describe how the WISEs in their study created social benefits for both the individuals providing the care, as well as the recipients. However, by typical measures of performance, for-profit competitors would be judged more efficient based on the number of participants they place into work, rather than the combined benefit of assess each participant on their merits. Powell et al (2019) have indicated much the same: social enterprise hybrids can manage competing logics to deliver service quality and serve a social mission effectively. And yet, no measurement framework exists that can capture multiple performance measures related to these logics, although more recent practical developments, such as the Social Enterprise Reporting Tool offer significant potential in this regard (Mason, Barraket, Elmes and Simnett 2018).

Studies of social enterprise performance indicate that the production of significant social benefits is often supported by a resilient business model and commitment to entrepreneurship and innovation (Bagnoli and Megali 2011). That said, there is also evidence to suggest that social enterprises often experience significant organisational tensions, arising from their hybrid nature and those typically experienced during the organisational life cycle (Bull 2008; Teasdale 2012b). One of the key tensions that social enterprises face is the relatively high resource intensity of regular performance measurement. In order to capture multiple social and economic impacts, social enterprises often struggle at the best of times to commit to ongoing reporting processes unless they have available systems to collect and process the data and staff commitment to ensure the rigour of the process and to produce reports. There is evidence that involvement in the delivery of public programmes within a quasi-market arrangement can actually increase the performance monitoring and reporting load upon organisations (see Department for Communities and Local Government 2014: p. 29). Thus, social enterprises may need to increase costs significantly in order to ensure that they can meet contractual requirements. This aspect alone may price out all but the largest social enterprises from engaging in government contracts. 
Moreover, the provision of services within a quasi-market context often requires the ability to determine that certain policy outcomes have been achieved and that the results can be attributed to the actions of the service provider in question; in this case the social enterprise. There are multiple challenges both in specifying appropriate outcomes in the first place, which can be both complex and controversial, but also in attributing the accomplishment of outcomes to policy inputs and ensuring appropriate recognition and reward to organisations for bringing about such outcomes. The rise of Social Impact Bonds (SIBs) as an alternative source of impact investing capital for social projects adds further complexity. SIBs are a form of Payment by Results PbR), 'bringing together socially motivated private finance and social organisations to provide outsourced public services' (Floyd 2017, p.1). As SIBs become more popular with government, we are beginning to get some idea of what performance measures look like in areas connected to quasi-markets where social enterprises operate. To this end, the notion of contracting out to social enterprises brings further stipulations to deliver service level agreements may also bring expectations on how performance is measured and what this means for business viability (as well as sustained social impacts - see Sinclair et al, 2019). Hurri et al (2016) showed in their study of Finnish health care quasi-markets that contracting has performance implications for organisational choice - noting that arising information asymmetries in contracting processes are likely to exacerbate such challenges.

How well any particular organisation can actually deliver outcomes is often questionable; their results may depend more upon wider economic or other environmental changes and the responses of users to the services and opportunities offered to them. Such results may, in fact, occur irrespective of the actions of those providing services. There is no evidence that social enterprises have the necessary expertise to successfully resolve such questions. Indeed, the lack of a robust evidence base and understanding of factors such as causality may, in fact, discourage the kind of innovation that is a supposed justification for the involvement of social enterprises in the provision of public services in the first place.

\section{Conclusions}


In this article, we explored the emergence of quasi-markets in tandem with the development of changing relationships between government, the market and the third sector. Specifically, have contributed a critique of the emerging body of research on social enterprises in quasimarkets, and consider that the interlinked issues we raise are relevant to scholars, policymakers and practitioners alike. The article focussed on the dominant trends of social enterprise participation in quasi-markets and proposed four critical gaps that are either not addressed in the broader third sector critiques or propose different implications for social enterprises. Each of the four core themes we have presented has significant implications for future research.

Regarding our first critical issue, boundary shifts in welfare markets and provision have radically altered power relationships and expectations between provider and service user. Such changes place responsibility for choice in the hands of the service users, while placing increased responsibility for adequate service provision in the hands of individual providers. As emerging quasi-markets indicate, such as the National Disability Insurance Scheme in Australia, the shifting boundaries have been promoted as a common-sense solution to wider government fiscal challenges (Walsh and Johnston 2013). Although these changes affect nonprofits and social enterprises alike, we do not currently understand how social enterprises and service users interact amid these changing market conditions. Understanding how new or reformed relationships between organisations and service users would uncover the frontline impact of social enterprises in quasi-markets.

Social enterprise has a political expediency due in large part to their hybridity. The question is whether social enterprises are better suited than other third sector actors to handle the changing relationships and boundaries that arise from quasi-market restructuring. We argue that there is a strong instrumental basis for social enterprise participation in quasi-markets, which diminishes their moral and ethical contributions to the characteristics of the market. Further research could address the moral case for social enterprise participation in quasimarkets in more depth. 
Secondly, the related gap of symbolic legitimacy tactics prompts deeper consideration of the basis for legitimacy in a social enterprise. The emergent critical research on social enterprise and entrepreneurship has already shown a need for a reconsideration of the imaginative possibilities inherent in this concept. For example, the notion of tactical mimicry has significant implications for studies of social entrepreneurial identity. Future research could extend both Dey and Teasdale (2016) as well as micro-linguistic analysis such as Parkinson and Howarth (2008) to understand the impact of market forces on how social enterprises are portrayed. This poses a number of interesting theoretical implications, including: how existing non-profit providers re-position themselves if they shift to a social enterprise model; whether for-profit providers experience a 'profit' mission drift once they successful re-badge as a social enterprise (Ebrahim, Battilana and Mair 2014); whether particular social enterprise models are favoured by tactical switchers (and why); and whether tactical mimicry erodes the notion of an 'authentic' social enterprise.

Thirdly, perhaps due to the relative nascence of social enterprise in quasi-markets, the empirical evidence base is thin. Single country-based studies, particularly those focusing on the NHS in England and Scotland, form the bulk of empirical and evaluative work to date. We propose that, although the evidence base is likely to continue its steady growth, other comparative assessments are needed. One such approach could be to adopt a realist evaluation approach, providing a valuable program-oriented framework for assessing social enterprise activities (Pawson and Tilley 2009; Pawson 2013). This will provide a clearer picture of how different approaches and programs can be judged according to participant choice. This is important in these early stages of social enterprise/quasi-market relations. Since we know little at the service user level, realist evaluation will explore the confluence of personal values alongside resources that inform service decisions. Thus, policy makers would be able to understand the 'triggers' lead to service choice, given context dependent factors.

Finally, the issue of how to resource social enterprise to report their performance effectively and appropriately to funders requires further consideration. Given the tensions inherent in the balancing mission and model, social enterprises might be disadvantaged in accounting for their performance due to their newness in the market and lack of established systems and 
expertise in providing the reporting required. This problem is intensified considering against the resources (including market experience) available to more established (and non-hybrid) non-profit providers, as well as for-profit providers. Failing to recognise the resource intensity of performance evaluation could stymie social enterprise development in quasi-markets, thus working against the aim of increasing organisational participation and diversity. Further research might explore organisational and service-user impacts as a consequence of these challenges, to help explain the types financial and non-financial resource constraints present.

Researchers are increasingly drawn to studying the political undercurrents that continue to influence the continued transformation of service delivery. The roll-out of quasi-markets have undoubtedly presented a range of opportunities for social enterprises, but also significant risks both to the organisations themselves and to wider society, which require to be reconciled. Research has, and will undoubtedly continue, to study how social enterprises navigate quasi-markets. However, the extent to which they are able survive in increasingly challenging and competitive welfare markets, remains to be seen. 


\section{References}

Adnett, N, Davies P. Schooling reforms in England: from quasi-markets to co-opetition? Journal of Education Policy. 2003 Aug;18(4):393-406.

Aiken, M. and Bode, I. (2009), Killing the golden goose? Third sector organizations and backto-work programmes in Germany and the UK, Social Policy \& Administration, Vol. 43, No. 3: pp. 209-225.

Alcock, P. (2014), Social Policy in Britain, Houndmills, Basingstoke, Hampshire: Palgrave Macmillan.

Alcock, P. and Kendall, J. (2011), Constituting the third sector: processes of decontestation and contention under the UK labour governments in England, VOLUNTAS: International Journal of Voluntary and Nonprofit Organizations, Vol. 22, No. 3: pp. 450-469.

Bagnoli, L., \& Megali, C. (2011). Measuring performance in social enterprises, Nonprofit and Voluntary Sector Quarterly, 40, 1: 149-165.

Bartlett, W. and Le Grand, J. (1993), The Theory of Quasi-Markets. In Le Grand, J. and Bartlett, W. (eds), Quasi-Markets and Social Policy, Houndmills, Basingstoke, Hampshire: Macmillan Press, pp. 13-34.

Battilana, J. and Lee, M. (2014), Advancing research on hybrid organizing - insights from the study of social enterprises, The Academy of Management Annals, Vol. 8, No. 1: pp. 397441.

Baxter K, Rabiee P, Glendinning C. Managed personal budgets for older people: what are English local authorities doing to facilitate personalized and flexible care? Public Money \& Management. 2013 Nov;33(6):399-406.

Bevan, G., Karanikolos, M., Exley, J., Nolte, E., Connolly, S. and Mays, N. (2014), The Four Health Systems of the United Kingdom: How Do They Compare? London: The Health Foundation/Nuffield Trust.

http://www.health.org.uk/sites/default/files/TheFourHealthSystemsOfTheUKHowDoTh eyCompare summary.pdf. (Accessed 13 February 2019) 
Billis, D. (ed). (2010), Hybrid Organizations and the Third Sector: Challenges for Practice, Theory and Policy, Basingstoke: Palgrave Macmillan.

Blackburn, R. and Ram, M. (2006), Fix or fixation? the contributions and limitations of entrepreneurship and small firms to combating social exclusion, Entrepreneurship \& Regional Development, Vol. 18, No. 1: pp. 73-89.

Blessing, A. (2012), Magical or monstrous? Hybridity in social housing governance, Housing Studies, Vol. 27, No.2: pp. 189-207

Bode, I., Gardin, L. and Nyssens, M. (2011), Quasi-marketisation in domiciliary care: varied patterns, similar problems? International Journal of Sociology and Social Policy, Vol. 31, No. 3/4: pp. 222-235.

Bolderson, H. (1982), Ambiguity and obscurity in policy-making for social security, Policy \& Politics, Vol. 10, No. 3: pp. 289-301.

Borzaga, C., \& Fazzi, L. (2014), Civil society, third sector, and healthcare: The case of social cooperatives in Italy. Social Science and Medicine, Vol. 123: pp. 234-241.

Bovaird, T. (2006), Developing new forms of partnership with the 'market' in the procurement of public services, Public Administration, Vol. 84, No. 1: pp. 81-102.

Braithwaite J, Makkai T, Braithwaite V. Regulating aged care: Ritualism and the new pyramid. UK: Edward Elgar; 2007.

Brandsen, T., van de Donk, W., \& Putters, K. (2005), Griffins or chameleons? Hybridity as a permanent and inevitable characteristic of the third sector, International Journal of Public Administration, Vol. 28, No. 9-10: pp. 749-765.

Bull, M. (2008), Challenging tensions: critical, theoretical and empirical perspectives on social enterprise, International Journal of Entrepreneurial Behaviour \& Research, Vol. 14, No. 5: pp. 268-275.

Calò, F., Teasdale, S., Donaldson, C., Roy, M. J., \& Baglioni, S. (2018). Collaborator or Competitor: Assessing the Evidence Supporting the Role of Social Enterprise in Health and Social Care. Public Management Review. Vol 20, No. 12: pp. 1790-1814. 
Carey, Dickinson, H., Malbon, E., Reeders, D., 2017. The Vexed Question of Market Stewardship in the Public Sector: Examining Equity and the Social Contract through the Australian National Disability Insurance Scheme. Social Policy \& Administration Online first. https://doi.org/10.1111/spol.12321

Carmel, E. and Harlock, J. (2008), Instituting the 'third sector' as a governable terrain: partnership, procurement and performance in the UK, Policy \& Politics, Vol. 36, No. 2: pp. 155-171.

Cheater, F. M. (2010), Improving primary and community health services through nurse-led social enterprise, Quality in Primary Care, Vol. 18, No. 1: pp. 5-7.

Considine, M. (2003), Governance and competition: The role of non-profit organisations in the delivery of public services, Australian Journal of Political Science, Vol. 38, No. 1: pp. 63-77.

Considine, M., Lewis, J. M., \& O'Sullivan, S. (2011), Quasi-markets and service delivery flexibility following a decade of employment assistance reform in Australia, Journal of Social Policy, Vol. 40, No. 4: pp. 811-833.

Considine, M., O'Sullivan, S. and Nguyen, P. (2014), Governance, boards of directors and the impact of contracting on not-for-profit organizations - an Australian study, Social Policy \& Administration, Vol. 48. No. 2: pp. 169-187.

Cornelius, N., \& Wallace, J. (2013), Capabilities, urban unrest and social enterprise: Limits of the actions of third sector organisations. International Journal of Public Sector Management, Vol. 26, No. 3: pp. 232-249.

Dart, R. (2004), Being 'business-like' in a nonprofit organization: a grounded and inductive typology, Nonprofit and Voluntary Sector Quarterly, Vol. 33, No. 2: pp. 290-310.

Dees, J.G. (1998), Enterprising nonprofits, Harvard Business Review, Vol. 76, No. 1: pp. 5467.

Defourny, J., Henry, A., Nassaut, S. and Nyssens, M. (2010), Does the mission of providers matter on a quasi-market? the case of the Belgian 'service voucher' scheme, Annals of Public and Cooperative Economics, Vol. 81, No. 4: pp. 583-610. 
Defourny, J. and Nyssens, M. (2010), Social enterprise in Europe: at the crossroads of market, public policies and third sector, Policy and Society, Vol. 29, No. 3: pp. 231-242.

Department for Communities and Local Government. (2014), Supporting People Payment by Results Pilots: Final Evaluation, HM Government, London. https://www.gov.uk/government/uploads/system/uploads/attachment_data/file/3622 70/Supporting People _ Payment by Results _ Final Evaluation.pdf. (Accessed 13 February 2019)

Dey, P., \& Teasdale, S. (2013), Social enterprise and dis/identification, Administrative Theory \& Praxis, Vol. 35, No. 2: 248-270.

Dey, P. and Teasdale, S. (2016), The tactical mimicry of social enterprise strategies: acting 'as if' in the everyday life of third sector organizations, Organization, Vol. 23, No. 4: pp. 485-504.

DiMaggio, P.J. and Powell, W.W. (1983), The iron cage revisited: institutional isomorphism and collective rationality in organizational fields, American Sociological Review, Vol. 48, No. 2: pp. 147-160.

Doherty, B., Haugh, H. and Lyon, F. (2014), Social enterprises as hybrid organizations: a review and research agenda, International Journal of Management Reviews, Vol. 16, No. 4: pp. 417-436.

Dowling, E. and Harvie, D. (2014), Harnessing the social: state, crisis and (big) society, Sociology, Vol. 48, No. 5: pp. 869-886.

Dunleavy, P. and Hood, C. (1994), From old public administration to new public management, Public Money \& Management, Vol. 14, No. 3: pp. 9-16.

Ebrahim, A., Battilana, J. and Mair, J. (2014), The governance of social enterprises: mission drift and accountability challenges in hybrid organizations, Research in Organizational Behavior, Vol. 34: pp. 81-100.

Evers, A. (2008), Hybrid organisations, background, concepts, challenges. In Osborne, S.P. (ed), The Third Sector in Europe: Prospects and Challenges, Abingdon, Oxon, Routledge: pp. 279-292. 
Exworthy M, Powell M, Mohan J. The NHS: Quasi-market, Quasi-hierarchy and Quasinetwork? Public Money and Management. 1999 Oct;19(4):15-22.

Ferguson, K. M. (2012), Merging the fields of mental health and social enterprise: Lessons from abroad and cumulative findings from research with homeless youths, Community Mental Health Journal, Vol. 48, No. 4: pp. 490-502.

Floyd, D. (2017). Social impact bonds: An overview of the global market for commissioners and policymakers. Technical report, Centre for Public Impact.

Glasby J, Littlechild R. Direct Payments and Personal Budgets: Putting Personalisation into Practice. Bristol, UK: Policy Press; 2009.

Hall, K., Alcock, P., \& Millar, R. (2012), Start Up and sustainability: Marketisation and the social enterprise investment fund in England, Journal of Social Policy, Vol. 41, No. 4: pp. 733-749.

Hall, K., Miller, R., \& Millar, R. (2016), Public, Private or Neither? Analysing the publicness of health care social enterprises. Public Management Review, Vol. 18, No.4: pp. 539-557.

Haugh, H. and Kitson, M. (2007), The third way and the third sector: new labour's economic policy and the social economy, Cambridge Journal of Economics, Vol. 31, No. 6: pp. 973994.

Hazenberg, R. and Hall, K. (2014), "Public Service Spin-Outs in the UK: Towards a Theoretical Understanding of the Spin-Out Process", Policy and Politics, Vol. 44 No. 3, pp. 441-463.

Hirschman, A. O. (1970), Exit, Voice and Loyalty: Responses to Decline in Firms,

Organizations and States, Cambridge, MA: Harvard University Press.

Hurri, J., Vuori, J., Liddle, J., \& Allen, P. (2016). The impact of quasi-markets on processes and factors affecting the costs of contracting. Policy Studies, 37(2), 1-19.

Institute of Public Care, 2015. Market shaping toolkit: supporting local authority and SME care provider innovation and collaboration.

Kendall, J. (2000), The mainstreaming of the third sector into public policy in England in the late 1990s: whys and wherefores, Policy \& Politics, Vol. 28, No. 4: pp. 541-562. 
Kerlin, J.A. (2006), Social enterprise in the United States and Europe: understanding and learning from the differences, Voluntas: International Journal of Voluntary and Nonprofit Organizations, Vol. 17, No. 3: pp. 247-263.

Le Grand, J. (1991), Quasi-markets and social policy, The Economic Journal, Vol. 101, No. 408: p. 1256.

Le Grand, J. (2011a), Quasi-market versus state provision of public services: some ethical considerations, Public Reason, Vol. 3, No. 2: pp. 80-89.

Le Grand, J. (2011b), Delivering Britain's public services through 'quasi-markets': what we have achieved so far, Research in Public Policy, Vol. Winter, No. 13: pp. 3-4.

Le Grand, J., \& Bartlett, W. (1993), Quasi-markets and social policy, London: Springer. Lewis, J. (2005), New Labour's approach to the voluntary sector: independence and the meaning of partnership, Social Policy and Society, Vol. 4, No. 2: pp. 121-131.

Lowery, D. (1998). Consumer sovereignty and quasi-market failure, Journal of Public Administration Research and Theory, Vol. 8, No. 2: pp. 137-172.

Mair, J., Mayer, J., \& Lutz, E. (2015), Navigating institutional plurality: organizational governance in hybrid organizations, Organization Studies, Vol. 36, No. 66: pp. 713-739.

Mason, C. (2012), Up for grabs: A critical analysis of social entrepreneurship discourse in the United Kingdom, Social Enterprise Journal, Vol. 8, No.2: pp. 123-140.

McDonald, C., \& Marston, G. (2008), Re-visiting the quasi-market in employment services: Australia's Job Network, Asia Pacific Journal of Public Administration, Vol. 30, No. 2: pp. 101-117.

McLean, J. and Ashton, T. (2001), Quasi-markets and pseudo-contracts in the New Zealand public health system, Otago Law Review, Vol. 10: p. 17.

Millar, R. (2012), Social enterprise in health organisation and management: Hybridity or homogeneity? Journal of Health, Organisation and Management, Vol. 26, No.2: pp. 143148.

Millar, R., \& Hall, K. (2013), Social Return on Investment (SROI) and Performance 
Measurement: The opportunities and barriers for social enterprises in health and social care, Public Management Review, Vol. 15, No. 6: pp. 923-941.

Millar, R., Hall, K., \& Miller, R. (2013). A Story of Strategic Change: Becoming a Social Enterprise in English Health and Social Care. Journal of Social Entrepreneurship, Vol. 4 No.1: pp. 4-22.

Miller, R., Millar, R., \& Hall, K. (2012), New development: Spin-outs and social enterprise: The 'Right to Request' programme for health and social care services, Public Money and Management, Vol. 32, No.3: pp. 233-236.

Nutt, K. (2016), Scotland's A\&E the best in world - Sturgeon hits back on health record, The National, Glasgow, 29 January. http://www.thenational.scot/news/scotlands-ae-thebest-in-world---sturgeon-hits-back-on-health-record.13026. (Accessed 13 February 2019.)

O'Brien, M. and Wilkes, C. (1993), The Tragedy of the Market: A Social Experiment in New Zealand, Palmerston North: Dunmore.

Osborne, S.P. (2006), "The new public governance?”, Public Management Review, Vol. 8, No. 3: pp. 377-387.

Osborne, S.P. (ed). (2010), The New Public Governance?: Emerging Perspectives on the Theory and Practice of Public Governance, London; New York: Routledge.

Parkinson, C., \& Howorth, C. (2008), The language of social entrepreneurs. Entrepreneurship and Regional Development, Vol. 20, No. 3: pp. 285-309.

Paton, R. (2003), Managing and Measuring Social Enterprises, London: SAGE Publications.

Pawson, R. (2013), The Science of Evaluation: A Realist Manifesto, Thousand Oaks, CA: SAGE.

Pawson, R. and Tilley, N. (2009), Realist evaluation. In Otto, H.-U., Polutta, A. and Ziegler, H. (eds), Evidence-Based Practice: Modernising the Knowledge Base of Social Work, Opladen: Barbara Budrich Publishers, pp. 151-180.

Peattie, K. and Morley, A. (2008), Eight paradoxes of the social enterprise research agenda, Social Enterprise Journal, Vol. 4, No. 2: pp. 91-107. 
Penn H. Childcare Market Management: How the United Kingdom Government Has Reshaped its Role in Developing Early Childhood Education and Care. Contemporary Issues in Early Childhood. 2007 Sep;8(3):192-207.

Pinch, S., \& Sunley, P. (2015). Social enterprise and Neoinstitutional Theory. Social Enterprise Journal, 11(3), 303-320.

Propper, C., Sutton, M., Whitnall, C. and Windmeijer, F. (2010), Incentives and targets in hospital care: evidence from a natural experiment, Journal of Public Economics, Vol. 94, No. 3-4: pp. 318-335.

Roy, M. J., Donaldson, C., Baker, R., \& Kay, A. (2013). Social Enterprise: New Pathways to Health and Well-being? Journal of Public Health Policy, Vol. 34, No. 1: pp. 55-68.

Roy, M. J., McHugh, N., \& Sinclair, S. (2017). Social Impact Bonds - Evidence-Based Policy or Ideology? In B. Greve (Ed.), Handbook of Social Policy Evaluation Northampton, MA: Edward Elgar Publishing Ltd, pp. 263-275.

Sinclair, S., McHugh, N., Huckfield, L., Roy, M.J. and Donaldson, C. (2014), Social impact bonds: shifting the boundaries of citizenship, Social Policy Review 26: Analysis and Debate in Social Policy, 2014: pp. 119-136.

Sinclair, S., McHugh, N. and Roy, M.J. (2019), Social Innovation, Financialisation and Commodification: A Critique of Social Impact Bonds, Journal of Economic Policy Reform, pp. 1-17.

Smith, S.R. (2010), Hybridization and nonprofit organizations: the governance challenge, Policy and Society, Vol. 29, No. 3: pp. 219-229.

Steiner, A. and Teasdale, S. (2016), The Playground of the Rich? Growing Social Business in the 21st Century, Social Enterprise Journal, Vol. 12 No. 2, pp. 201-216.

Struyven, L., \& Steurs, G. (2005). Design and redesign of a quasi-market for the reintegration of jobseekers: empirical evidence from Australia and the Netherlands. Journal of European Social Policy, 15(3), 211-229.

Taylor, B., Mathers, J., Atfield, T., \& Parry, J. (2011), What are the challenges to the big society in maintaining lay involvement in health improvement, and how can they be met? Journal of Public Health, Vol. 33, No. 1: pp. 5-10. 
Taylor, M., \& Bassi, A. (1998). Unpacking the state: the implications for the third sector of changing relationships between national and local government, Voluntas: International Journal of Voluntary and Nonprofit Organizations, Vol. 9, No.2: pp. 113-136.

Teasdale, S. (2012a), What's in a name? making sense of social enterprise discourses, Public Policy and Administration, Vol. 27, No. 2: pp. 99-119.

Teasdale, S. (2012b), Negotiating tensions: how do social enterprises in the homelessness field balance social and commercial considerations?, Housing Studies, Vol. 27, No. 4: pp. $514-532$.

Teasdale, S., Lyon, F., \& Baldock, R. (2013), Playing with numbers: A methodological critique of the social enterprise growth myth, Journal of Social Entrepreneurship, Vol. 4, No.2: pp. 113-131.

Walsh, J., \& Johnson, S. (2013), Development and principles of the National Disability Insurance Scheme, Australian Economic Review, Vol. 46, No. 3: pp. 327-337.

Warner, M. E., \& Clifton, J. (2014), Marketisation, public services and the city: The potential for Polanyian counter movements, Cambridge Journal of Regions, Economy and Society, Vol. 7, No. 1: pp. 45-61.

Warrilow, M., \& Jones, K. (2012), Setting up a social enterprise for clinician-led lymphoedema services, British Journal of Nursing, Vol. 21, No.21: pp. 1256-1261.

Veronesi, G., \& Keasey, K. (2012), A (new) model of board of directors: Evidence from the National Health Service, International Journal of Public Sector Management, Vol. 25, No. 4: pp. 272-286. 